\title{
Размишљања о личном имену и перифразама у Ланселоту у прози
}

\author{
Зорана В. Крсмановић* \\ Универзитет у Београду, Филолошки фракултет, Катедра за романистику
}

Кључне речи:

Ланселот у прози

француска

књижевност

XIII век

роман

лик

перифраза

окружење личног

имена

\section{Апстракт}

Предмет овог рада је анонимни старофранцуски роман Ланселот у прози настао између 1215. и 1230. године, средишњи део циклуса Ланселот-Грал или Вулгата, којем претходе Историја Светог Грала и Мерлин, а следе Потрага за Светим Гралом и Смрт краља Артура. Анализирамо функционисање и стилистичке импликације перифраза и окружења личног имена епонимског јунака Ланселота. Перифразе и лична имена показују односе између појединих витеза на које се односе и артуровског друштва, сведоче о еволуцији лика, о његовом идентитету, о међусобној повезаности појединих ликова. Важни су такође и за компоновање приче, као и повезивање прозног Ланселота са другим романима циклуса Вулгата, пре свега са Потрагом за Светим Гралом, романом који на известан начин припремају. Употребе личних имена и перифраза тако показују различите концепције романескног лика и стварање епонимског јунака. (примљено: 13. септембра 2021; прихваћено: 28. октобра 2021) www.anali.fil.bg.ac.rs

\section{АНАЛИ}




\section{1. Увод}

У овом раду се питамо како лично име и његове замене у виду проширених именских група или перифраза доприносе грађењу Ланселотовог (Lancelot) лика и његовој интеграцији у друштво витеза Округлог Стола. Игре око имена и надимака нису инвенција анонимног аутора прозног Ланселота, који је предмет нашег истраживања. Оне су веома распрострањене већ у романима о краљу Артуру и његовим витезима у стиху Кретјена де Tроа (Chrétien de Troyes) из друге половине XII века, на које се угледа творац циклуса Вулгата, као и у романима Жана Ренара (Jean Renart) на почетку XIII века. Ванеса Обри (Vanessa Obry) установила је да «Chez Chrétien de Troyes, l'entourage du nom propre reflète les relations entre son porteur et la société arthurienne, alors que chez Jean Renart, les variations sont plus nombreuses et témoignent d'une plus grande malléabilité des personnages » (2017: 1). ${ }^{1}$ У Ланселоту у прози (le Lancelot en prose), међутим, поред ових улога, игре именовања суптилни су механизми помоћу којих се међусобно повезују делови текста самог романа, као и роман са другим романима, пре свега са Потрагом за Светим Гралом (la Quête du Saint Graal) и Витезом на Колицима (le Chevalier de la Charrette) Кретјена де Троа.

Наша размишљања и анализе баве се превасходно ликом епонимског лика Ланселота у дугој верзији романа, али неминовно је његово повезивање и са другим ликовима, Гиневром (Guenièvre), Галехотом (Galehot), Галахадом (Galaad), Бохортом (Bohort), Лионелом (Lionel), Хектором (Hector), Говеном (Gauvain), краљем Артуром (le roi Arthur) и Госпом с Језера (la Dame du Lac). То је посебно значајно када су у питању перифразе и метафоре које се понављају и које дели са другим ликовима. Истраживање не претендује да буде исцрпно, с обзиром на то да би ова тема могла бити и предмет посебне монографије.

\section{2. Игре анонимности}

Већ у романима које је написао Кретјен де Троа, Ланселот или Витез на Колицима, Ивен или Витез са Лавом и Персевал или Прича о Гралу, « [...] le récit oppose des passages où le protagoniste est nommé et d'autres où, parce qu'il a perdu son nom ou parce qu'il ne l'a pas encore trouvé ou mérité, il est anonyme », наводи Обри (Obry, $2017: 9$ ). ${ }^{2}$

Веома важан поступак у роману јесте и чување анонимности епонимског лика. Иако читалац од самог почетка текста зна да се перифразе везане за детињство -„Пронађени Лепотан“, „краљевски син“, „Богато Сироче“, као и оне које сведоче о првим подвизима - „Бели Витез“, „онај који је освојио Болну Стражу“ и неке касније односе на Ланселота, аутор бира да га не именује. Ани Комб (Annie Combes) сматра да се улога перифраза огледа у намерном срозавању припове-

1 „Код Кретјена де Троа окружење личног имена одражава оносе између лика који је именован и артуровског друштва, док су код Жана Ренара варијације бројније и сведоче о већој променљивости ликова.“ Све цитате у овом раду превела је са француског и енглеског на српски језик ауторка чланка.

2 „[...] у причи се сучељавају делови текста у којима се протагониста именује са онима где је анониман зато што је изгубио своје име, што га још увек није нашао или заслужио.“ 
дачевог знања на ниво ликова, што делује као неспретност, а заправо је вештина која служи да се нагласи текстуални механизам: прихватајући приповедно решење Кретјена да се поштује анонимност главног лика све док га не укине краљица, прозни роман изнова ствара значајан ефекат Гиневриног именовања и на тај начин се прича Витеза са Колицима укључује у нову приповест (2000: 207).

Приповедачево чување тајне о идентитету јунака у Кретјеновом роману престаје од тренутка када краљица Гиневра именује Ланселота. Симболичка организација око имена које даје вољена жена у прозном роману јавља се два пута, дискретно у епизоди „Колица“ и наглашено, од тренутка када се витез придружи Артуровом двору (Combes, 2000: 204). Приповедач се претвара да је у незнању, као и ликови романа, када користи перифрастичне формуле „нови витез“, „витез са белом опремом“, „Бели витез“, „витез који је освојио замак“, „витез са носила“. Сам јунак све време зна сопствено име, као и у Кретјеновом делу, али га никоме не саопштава.

Роман у прози објашњава ово тајанствено ћутање витеза тако што наводи његово настојање да изгради име захваљујући подвизима, по савету помајке, Госпе с Језера (Micha, 1980a: 269). По тој ћутљивости и одбијању да открије свој идентитет он постаје препознатљив, ова црта његовог карактера види се и у једној епизоди при крају романа, када домаћин захваљујући томе препозна „најбољег витеза на свету“. Ланселот избегава да се представи витезима које среће с обзиром на то да не може да их препозна док су под витешком опремом, надајући се да ће избећи срамоту ако победи у борби или на турниру некога од витеза Округлог Стола, којем и сам припада. Такође, била би велика срамота ако би се неко борио са Ланселотом који је склопио мир између Артура и Галехота, пронашао Говена којег је отео џиновски витез Карадок и ослободио заробљене витезе-трагаче и постао омиљени пријатељ краља и краљице.

Чињеница да ова процедура опстаје и када Говен прозре тајну „господара Болне Страже“ показује колико је ефекат намеран: перифразе нестају када Галехоту откривају витезов идентитет, а резервисаност приповедача престаје у сцени љубавне изјаве Гиневри (Combes, 2000: 206). Ми се слажемо са ауторком, уз једну исправку: две врло занимљиве перифразе присутне су до краја романа и зато ћемо их посебно разматрати: „добри витез“ и „најбољи витез на свету“.

Име „Ланселота с Језера“ на Артуровом двору открива краљев сестрић Говен, после успешно завршене потраге за њим, а не краљица Гиневра у земљи Гор, на двору краља Бодемагија, као што је то било у стиховном роману. Ово је важан детаљ који показује аутономију прозног романа у коме, не негирајући значај љубави према краљици, већи значај добијају витешко пријатељство и витешки подвизи и потраге уопште у односу на свемоћну алегоризовану Љубав која води протагонисту од срамоте „витеза на Колицима“ до славе именованог победника и јунака ослободиоца у делу Кретјена де Троа. Верност стиховном роману се показује у томе што се анонимност Ланселота чува и после Говеновог открића, све док краљица Гиневра не буде открила његов идентитет краљу Бодемагију, приликом преласка Моста Мача у епизоди „Колица“. 


\section{3. Лично име и двострука природа витештва: мотиви изгубљеног и пронађеног имена}

На почетку романа Ланселот у прози приповедни глас приче саопштава читаоцима да ће сазнати нешто о имену главног јунака: « [...] et avoit non Lancelos en surnon; mais il avoit non en baptesme Galaaz. Et che pour coi il fu apeleis Lancelos, che

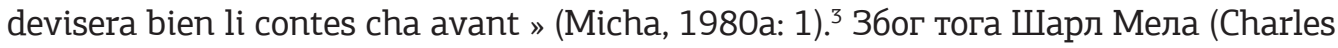
Méla) с правом сматра да се овај роман може схватити као „елуцидација личног имена“, тврдећи: « L'unité contradictoire du Lancelot est toute entière contenue dans le double nom du héros : "Galahad » en baptême, mais «Lancelot » d'après son aïeul, et le premier nom reste longtemps en sommeil, jusqu'au jour où cette dualité s'avère incompatible et exige son report de père en fils, c.à.d. dans la génération, de Lancelot à Galahad, désormais distincts, mais aussi bien dans la récurrence généalogique de l'aïeul «Lancelot » à l'ancêtre « Galaad » » (1984: 332). ${ }^{4}$ Уколико прихватимо ове ставове, у роману можемо да пратимо како витез гради идентитет покушавајући да пронађе непознато име и настојећи да поврати, премда безуспешно, „изгубљено име“. Приликом Галахадовог зачећа приповедач напомиње да ће син повратити изгубљено очево име, као и да ће грех пожуде бити укинут захваљујући телесном уздржавању девичанског витеза (Micha, 1979: 211).

У Ланселотовом портрету јавља се перифраза краљице као оне «dont toute sa joie venoit », будући да му она улива самопоуздање и подстиче га на стално самопревазилажење (Micha, 1980a: 74). ${ }^{5}$ Ово именовање Гиневре одјек је идеје из Кретјеновог Витеза на Колицима, где се у сцени ноћне посете краљици говори о витезовој неизрецивој радости због остварења љубави и успешно завршене потраге за отетом краљицом. Реч „радост“ није случајно изабрана, она је пренесена из лирске поезије у пустоловни роман и означава почетак пустоловина и њихов крај, као и границе епизода и секвенци. Радост је циљ којем теже заљубљени лирски субјекти, који је досежу тако што стварају савршену песму, а лутајући витези у романима тако што успешно завршавају своје пустоловине. Из ове перспективе, љубав према краљици представља извор Ланселотовог непоновљивог витештва, што потврђује и говор Госпе с Језера, а то заправо читав роман настоји да покаже. С обзиром да је та љубав прељубничка и грешна, њен домет је ограничен: она, уз наслеђени грех краља Бана, постаје препрека у потрази за Гралом. Сам Ланселот постаје „извор све радости“ краљице, као и читавог двора који очекује његов повратак, после дугогодишњег одсуства. Он је, симболично, „радост двора“, а приповедач га ингениозно назива „почетком и крајем потраге“.

3 [...] и звао се Ланселот по надимку, али крштено име му је било Галахад. А о томе зашто је назван Ланселот причаће прича нешто касније“.

4 „Контрадикторно јединство Ланселота у потпуности се огледа у двоструком имену јунака: „Галахада“ на крштењу, али „Ланселота“ по свом претку, и прво име дуго почива, све до дана када се тај дуалитет покаже као некомпатибилан и захтева преношење са оца на сина, односно генерацијски, од Ланселота ка Галахаду, који се од тада разликују, али такође у генеалошком понављању од претка „Ланселота“ до претка „Галахада“.”

5 „од које је потицала сва његова радост“ 
Миреј Сеги (Mireille Séguy) истиче да краљица даје идентитет првим ословљавањем епонимског јунака именом „Ланселот“, које замењује првобитни идентитет који је добио од Бога са крштеним именом „Галахад“: « [...] tout se passant comme le sur-nom courtois était venu recouvrir, puis effacer, le nom mystique repris plus tard par le fils de Lancelot » (1996: 23). ${ }^{6}$ Слажемо се са ауторком овог чланка да је тај губитак имена све болнији како приповест одмиче и како се све учесталије помиње Грал; то ће се показати и у употреби перифраза. Такође, оно на чему је почивала његова вредност управо ће га лишити најпрестижнијег места међу Артуровим витезима, с тим да не долази, како Сеги с правом каже, до „рушења јуначке фигуре“ ( effondrement de la figure du héros »), већ до њеног „слабљења“ (« creusement ») (1996: 23).

Једна од битних опозиција у роману тиче се концепција „земаљског“ и „небеског“ витештва (chevalerie terienne vs. chevalerie célestielle). Читав прозни Ланселот, као и циклус Вулгата, показују недовољност „земаљског витештва“, истовремено га славећи, пошто без њега нема ни „небеског витештва“. Пут који лик Ланселота прелази и трансформације кроз које пролази показују овај контраст. Потребно је да укратко резимирамо радњу романа, како би ово било јасно. Ланселот је син краља Бана Беноака из Галије и остао је без поседа и без оца због узурпатора Клодаса. Краљ Артур због ратова које је водио није могао да помогне свом вазалу, краљу Бану, у рату са Клодасом. Госпа с Језера одвела је Ланселота у свој свет, а његова мајка се замонашила. Разбаштињени су и његови рођаци, Бохорт и Лионел, чији је отац брат краља Бана. Када је дете порасло, вила га је довела на двор краља Артура, са жељом да се прослави и да поврати изгубљено краљевство. Прељубничка љубав према жени краља Артура, краљици Гиневри, ремети типичну схему напретка митског јунака. Ако је због те љубави постао најбољи представник земаљског витештва, надмашивши узорног Говена, грех пожуде га је учинио недостојним свог крштеног имена „Галахад“, као и учешћа у пустоловинама Светог Грала. У томе се огледа трагика овог лика. Он до краја остаје Ланселот са Језера, суштински везан за вилински свет своје помајке, краљице Гиневре и Моргане, за домен земаљског витешког света испуњеног бретонским чудима. Његов син Галахад, оличен у симболима лава и цвета, постаје „цвет свег витештва“, модел савршено исправног небеског витеза. Витези слични њему по девичанству (Персевал) и по моралној чистоти (Бохорт) имају привилегију да буду названи истом перифразом „Добри Витез“, док у последњој трећини романа његов отац губи то право. Зато ће ова три припадника млађе генерације учествовати у потрази за Гралом, док ће « la flors de la terriene chevalerie ", Ланселот, из ње бити искључен, упркос неуспелом покушају покајања (Micha, 1978: 107). ${ }^{7}$ Шарл Мела примећује да је Ланселот „сазнао да је искључен из потраге за Гралом у тренутку када му је откривено Галахадово име, да би затим симболично били нарушени његово здравље и ле-

6 „[...] све се дешава као да је куртоазно над-име ту да прекрије, а затим избрише, мистично име које ће касније поново узети Ланселотов син."

7 „цвет земаљског витештва“ 
пота“; слажемо се са аутором да се у томе огледа „величина овог дела“: « Mais la grandeur de l'œuvre est qu'il [...] se sache exclu du Graal à l'instant où lui est révélé le nom de Galaad ; puis qu'il en ressente symboliquement l'atteinte en son corps et en sa beauté [...]» (1984: 352).

Поред тога, подсетили бисмо на једно именовање Ланселота коју даје лик краља Бодемагија у роману Ланселот или Витез са Колицима Кретјена де Троа. Покушавајући да уразуми свог сина Мелеагана и одврати га од борбе, назива га «li miaudres chevaliers del monde » (Fritz et al., 1994: 593). ${ }^{8}$ Док стиховни роман обрађује само једну епизоду из живота јунака, о коме немамо никакве информације, ни о пореклу, ни о припадности феудалном господару, нити о његовим пустоловинама, у прозном роману који има биографску структуру сазнајемо како Ланселот постаје „најбољи витез на свету“ и како престаје да то буде, када се иста перифраза односи на његовог рођака Бохорта, полубрата Хектора и сина Галахада. Ланселот са Језера јесте „најбољи витез на свету“ у првом делу романа, све до појаве Грала у епизоди „Колица“, док се истичу подвизи тзв. „земаљског витештва“. У тим епизодама се за епонимског јунака користи перифраза „Добри Витез“, која ће се почев од прве најаве Галахадовог зачећа усред епизоде „Колица“, све чешће односити на будућег витеза, који ће успешно завршити потрагу за Светим Гралом и завршити све пустоловине у Артуровом краљевству Логр. Док су приповедни глас приче и сам протагониста свесни Ланселотове деградације, неки ликови га до краја романа називају овим перифразама, дивећи се како његовом јунаштву, тако и лепоти.

Данијел Поарион (Daniel Poirion) истиче да у романима о краљу Артуру « [...] l'aventure est en dernière analyse une confrontation avec soi-même. C'est pourquoi le motif du nom retrouvé (Lancelot, Perceval, le Bel Inconnu) apparaît au terme d'une première série d'aventures conduisant à la connaissance du soi, ou à la reconnaissance de soi, tandis qu'une autre série d'aventures peut poser le thème du dépassement de soi, ambition normale du héros aristocratique " (1988: 122). ${ }^{9}$ Млади Ланселот од Госпе с Језера добија лекцију о витештву и наредбу да никоме не открива своје име све док се не потврди његова вредност захваљујући разним подвизима, слично као што је Персевалова мајка у Кретјеновој Причи о Гралу рекла сину да « Par lo sornon conoist en l'ome » и да увек треба да пита сапутнике за име (Fritz et al., 1994: 958). ${ }^{10}$ Ланселот ће на свом путу стећи многа имена и надимке, у сладу са тренутним друштвеним статусом, али и самовредновањем.

Миреј Сеги сматра да је фигура Ланселота примерна по томе што сведочи о индивидуалној слободи и принципу избора и остварења сопствене судби-

8 „најбољим витезом на свету“

9 „[...] пустоловина је у крајњој инстанци суочавање са самим собом. Због тога се мотив пронађеног имена (Ланселот, Персевал, Лепи Незнанац) појављује на крају првог низа пустоловина које доводе до сазнања о себи или препознавања себе, док неки други низ пустоловина може да уведе тему самопревазилажења, које је нормална амбиција аристократског јунака.“

10 „По имену се познаје човек.“ 
не, током потраге за собом, пошто је „раскрштен од свог програмског имена“ (« débaptisé de son nom-programme ») (1996: 27).

\section{4. Перифразе и програмирано приповедање}

Даглас Кели (Douglas Kelly) наводи да средњовековни поетичар Џефри из Виносалва (Geoffrey de Vinosalvo) сврстава перифразу у поступак амплификације, саветујући писцима да избегавају да зову ствари њиховим именом, те да радије сугеришу путем наговештаја него да потпуно откривају (1992: 59). Она служи као украс, са чиме се слаже и Матеј из Вандома (Mathieu de Vendôme), који сматра да је то начин да се да сјај предметима или ублажи ружноћа (Faral, 1982: 68). У прозном Ланселоту перифраза није само средство украшавања, већ указује на значење које аутор хоће да наговести оваквим изражавањем, као што су грађење и метаморфозе идентитета главног лика или степени витештва.

Грчка реч „реriphrasis“ означава именовање неког појма посредним, описним путем, а не његовим правим именом (Клајн/Шипка, 2007: 921). По перифразама се види да је Ланселот лик у настајању, свим другим главним ликовима не крију се име, титула, нити порекло. Тако Говен, на пример, често наглашава да никада не крије своје име када му затраже да се представи. Његов једини покушај да сакрије свој идентитет од својих другова није уродио плодом, а у тексту се јасно истиче да је том лукавству прибегао сетивши се Ланселотовог скривања.

Три перифразе које се јављају током боравка у домену Језера програмирају судбину епонимског лика: « li Biau Trouvé » $и$ « Riche Orphenin » називи су које му је дала помајка, док га остали зову « fil de roi » (Micha, 1980a: 43-44). ${ }^{11}$ Овај поступак налази се и у француском средњовековним романима о Тристану у стиху Томаса и Берула, с тим што у њима лично име, а не перифраза, има ту улогу: Тристан је по својој природи „тужан“ (« triste ») и та туга је програмирана, пошто му је мајка дала име у складу са несрећним оконостима у којима се родио (отац му је убијен, а мајка умире на порођају). ${ }^{12}$ Ланселотов надимак „Пронађени Лепотан“ програмира пустоловине и лутања овог лика: његова лепота задивљује многе жене, нарочито оне вилинске природе, а цела радња романа се организује око потрага за овим ликом. „Пронађени Лепотан“ ће постати предмет пет потрага, изазиваће дивљење жена и девојака (девојке неговатељице код отрованог извора, девојке код црног бунара, трију чаробница - Моргане, Сибиле и краљице из Сорестана), али и витеза, као што је Ивен, који на почетку каже да је он „si biau vallet“ (Micha, 1980a: 268)13. Многи Артурови витези, као и девојке и жене у невољи или страни витези, тагају за њим, тако да се ово име остварује кроз приповедни програм овог романа, по принципу nomen est omen (име је знамење). Његово проналажење и повратак на Артуров двор, а затим изненадни нестанак или планирани одлазак, представљају образац који се понавља.

11 Надимци су, редом: „Пронађени Лепотан“, „Богато Сироче“ и „краљевски син“.

12 Многи медиевисти помињу текстове у којима се истиче ова идеја, види Séguy, 1996: 27, 32.

13 „тако леп младић“ 
Госпа из Малехота, у чијем је затвору Ланселот провео годину дана, заљубљује се у њега и радује што је « che que nus ne puet avoir » под њеном влашћу (Micha, 1982: 44). ${ }^{14}$ За разлику од тога, када Ланселот прекине рат између Галехота и краља Артура, краљ тугује због « del boin chevalier » kojи ће припадати Галехотовој кући; у овом конкретном случају, перифразом се велича његово витештво, а не чудесна лепота (Micha, 1982: 30). ${ }^{15}$ Његова доброта ће се појавити уз лепоту у Бохортовој похвали Говеновом брату Агравену, са којим се борио како би доказао да је Ланселот бољи витез од Говена: «L'en apele, fet Boors, mon seignor Lancelot del lacs, si est li plus bials chevaliers del monde » (Micha, 1978b: 182). ${ }^{16}$ Перифраза „најбољи и најлепши витез на свету“ такође се јавља када Ланселот успешно укине чаролију магичног кола, ослободивши његове затворенике; тим подвигом је доказао да је неоспорно најбољи и најлепши, како наводи један лик-сведок (Micha, 19796: 287). Над „најлепшим витезом на свету [...] који је изгубио разум“ сажалио се један мудри пустињак: « [...] et lor dist qu'il a trouvé en cele forest le plus biaux chevalier dou monde [... ] « mais si grant mescheance, fet il, il est avenue qu'il est fors del sens » »(Micha, 1980c: 218). ${ }^{17}$ Лик Ланселота је овде приказан као жртва несрећне судбине, „велике несреће“ (« grant mescheance »), при чему аутор користи спој неспојивог, спајајући изузетну лепоту, која је обично знак и доброте, односно витешке вредности, са лудилом које изопштава витеза из друштва и мења његов идентитет. У другим деловима текста, болесни и оронули Ланселот ипак је предмет потраге многих, који траже „доброг витеза“, али епизода на Острву Радости, која претходи доласку младог Галахада на Артуров двор, потврђује да је деградација Ланселотовог лика непоправљива, пошто и он сам установљује лош обичај, попут оних које је током читаве витешке каријере укидао као јунак ослободилац. Надимак „Пронађени Лепотан“, које је Ланселоту дала Госпа с Језера, има чудесну моћ да ублажи Ланселотово лудило услед раздвојености од Галехота у затвору саксонске чаробнице Гамије (Micha, 1982: 458).

Уочили смо и везу између перифраза које се односе на тројицу рођака: Ланселота као „Пронађеног Лепотана“, Бохорта као „Лепог Стидљивка“ у замку краља Брангоара и Лионела као „Необузданог срца“, како га је назвао Галехот током потраге за Ланселотом. Ланселота са Бохортом повезује лепота, а са Лионелом изузетна храброст. „Неумерено срце“ Лионела и „исувише велико срце“ Ланселота сведоче о снажним емоцијама које покрећу ове ликове да чине племенита дела, али због којих су и веома гневни када сведоче некој неправди. На тај начин се истиче значај генеалогије и хередитарности (витези из Ланселотове лозе су лепи и племенити) и поштује идеал калокагатије, наслеђен из позне Антике.

14 „онај кога нико не може да има“

15 „доброг витеза“

16 „Зову га, рече Бохорт, господином Ланселотом с Језера, он је најлепши витез на свету.“

17 „[...] и рече им да је у тој шуми пронашао најлепшег витеза на свету [...] „али тако велика несрећа, рече он, десила му се па је изгубио разум“.” 
„Краљевски син“ је назив који се допао младом Ланселоту, који признаје Госпи с Језера би волео да му је срце заиста тако племенито и да заслужи да га тако зову; врло брзо по изласку из света своје помајке он сазнаје да јесте краљевског порекла и показује своју вредност. Помајка му не открива порекло, пошто тако престижно име мора да се заслужи врлим делима; овај поступак сведочи о идеологији сталног усавршавања аристократа која је на делу и у артуровским романима у стиху. Међутим, наследник краљевства одбија да седне на чудесни трон (који је саградио његов отац) и да стави круну у епизоди у Долини Лажних Љубавника, као и да влада поседима које му је повратио краљ Артур у рату са Клодасом. Ћерка господара из Бретеше хвали његове врлине, истичући да има потенцијал да постане " rois de tot le mont " (Micha, 1979: 27). ${ }^{18}$ Ова перифраза очигледно нема феудалну вредност, већ се односи на моралну изврсност и савршенство јунака, који је, попут краља, чувар реда и цивилизације. Међутим, у Корбенику Ланселот успева у пустоловини са Опасним креветом „који је достојан краља“, па бисмо могли да претпоставимо да овде он постаје двојник краљевске фигуре.

Перифраза „Богато Сироче“ даје митско обележје епонимском лику, који је попут многих других одгојен на другом свету и треба да освоји изгубљено краљевство, крене у потрагу за невестом и сам постане краљ. Љубав према краљици га удаљава са тог пута и води га ка томе да његов идентитет никада није стабилан.

\section{1. Перифразе „најбољи витез на свету“ и „добри витез“}

Данијел Поарион истиче да се у романима Кретјена де Троа „пустоловина тиче једног имена, једног мушкарца, јунака који влада собом и који у датом тренутку представља најузвишенију људску вредност“: « Chez Chrétien de Troyes, l'aventure concerne un nom, un homme, le héros de la maîtrise de soi qui constitue, à cette époque, la plus haute valeur humaine » (1988: 123). У Ланселоту протагониста има више двојника, што се може уочити и путем анализе перифраза. Перифразе „добри витез“ и „најбољи витез на свету“ релативно су фиксни супститути имена, премда се некад појављују и уз име „Ланселот“ или „Ланселот са Језера“.

По Ани Комб, перифраза „најбољи витез на свету“ сведочи о томе да је прозни Ланселот џиновска експанзија израза којим у Кретјеновом роману краљ Бодемаги назива ослободиоца краљице; тако је прва дефиниција јунака управо она коју је дао Кретјен де Троа, све до тренутка када он престане да буде најбољи (Combes, 2000: 192).

Уочили смо укупно четрдесет једну појаву перифразе „најбољи витез на свету“, која се понекад јавља у скраћеном виду „најбољи витез“ или се проширује придевима или другим синтагмама: „најбољи и најпустоловнији витез на 
свету“, „најбољи витез на свету и највернији драган““. ${ }^{19}$ Када је реч о дистрибуцији, тридесет три пута се користи да означи Ланселота (80,49\%), али од тога ликови у пет наврата доводе у питање овакав статус лика (12,91\%), једном он сам то чини $(2,44 \%)$, а изузетност се релативизује у три наврата, где се помиње да је Ланселот само „тренутно најбољи витез на свету“ или „најбољи витез на свету од оних који сада живе“, „најбољи земаљски витез“ (7,14\%). Искључиво позитивна конотација престаје од тренутка када Хектор и Галехот улазе у приповест. Доминира употреба директног говора ликова (92.68\%); остали случајеви су натписи на надгробним плочама и преношење мисли лика путем гласа приповедача (7,31\%). Ланселота хвале и диве му се: Брандиса, домаћица после првог турнира у Камелоту, краљица Гиневра, девојка Госпе с Језера, Говен, Бохорт, Елије из Тулуза, уплакана девојка, девојка која води Говена и Ивена, Морганина девојка, један старији човек који показује штит Галехоту, домаћица код Корбеника, грађани Корбеника, један стари витез, краљ Артур, домаћин и Маранова сестра. Његов статус најбољег доводи у питање рањени домаћин, због тога што га није препознао; чим му је краљ Бодемаги рекао да је у питању Ланселот са Језера, он полази у потрагу за њим, који једини може да га излечи. Ланселотову изврсност оспорава један агресивни витез у препирци са девојком коју злоставља, а коју ће Ланселот ослободити, наводећи да није могуће да син лошег краља Бана буде најбољи витез на свету. Бруман Охоли, који нешто касније оспорава његову храброст и реноме најбољег, седа на Опасно Седиште и страда. Чак и Говен наводи да је најбољи витез донео многе невоље на Артуров двор, понизивши и намучивши витезе из куће краља Артура. Ово је детаљ који може деловати безначајно, али при крају романа се описује растућа завист према успеху Ланселотове браће и њега самог, као и сукоб између Говенове и Ланселотове породице, што ће бити један од разлога слома краљевства у последњем роману циклуса. Иако најбољи бранилац Логра, он је заслужан и за његову пропаст, што чини фигуру Ланселота људском.

Иста перифраза користи се за друге витезе: Хектора, Говена и Клодасовог сина Клодена (један случај, односно 2,44\%), Бохорта (два пута, 4,87\%) и Галахада (три пута, 7,31\%). Већ и сама дистрибуција указује на хијерархијски систем вредности, где управо двојица витеза из Ланселотове лозе постају успешни трагачи за Гралом, док су остали или јако вешти ратник - млади Клоден ${ }^{20}$ у рату Артура са Клодасом, примерни бранилац жена - Говен као „најбољи витез који је икада носио копље“ или јунак ослободилац заслужан за „радост двора“ - Хектор који је победио Марганора.

Почев од Елијевог тумачења Галехотових снова и најаве Галехотове смрти, Ланселотов престиж најбољег постаје временски ограничен, најављује се „бу-

19 Због бројних помињања наводимо све појаве наведене перифразе овде, пратећи редослед приче романа, а не хронологију објављивања Мишиног критичког издања: Micha, 1980a: 360, 430; Micha, 1982: 121, 207, 235, 302, 330, 335, 422, 462; Micha, 1978a: 52, 188, 256, 325, 326, 361; Micha, 1978b: 35, 177, 182, 374; Micha, 1979: 111, 197, 202, 217, 236, 287, 304, 354, 390; Micha, 1980b: 68, 69, 101, 110, 119, 120, 139, 218, 246; Micha, 1980c: 25, 168, 224, 236.

20 у Потрази за Светим Гралом Клоден ће бити један од привилегованих витеза које ће хранити Грал, у последњој сцени у Корбенику. 
дући најбољи витез који ће завршити пустоловине у Британији и заузети последње седиште Округлог Стола“ (Micha, 1978a: 52), „најбољи витез на свету који је потпуно невин“, који ће угасити чудесну ватру кипућег извора и за кога је предодређена пустоловина са белим јеленом (Micha, 1980b: 120) - Галахад, „син најбољег витеза на свету и ћерке Краља Рибара која је најлепша девојка“ (Micha, 1980b: 139). Помињање Галахада везује се за Мерлинова пророчанства, појављује се на натпису надгробне плоче Симеона, а глас наведеног претка саопштава му име будућег детета и обавештава га да он више није најбољи витез на свету. Ланселот пре појаве гласа истиче да се најбољи витез не би плашио гласа који се чује из гроба, он је врло свестан да му се статус променио. Ова епизода илуструје везу између именовања и чудесне пустоловине, о којој Кели наводи следеће: "Appellation demonstrates the election or rejection of the name bearer by the marvels he or she knows or fails to know through adventures." (1992: 200). ${ }^{21}$

Кад је реч о перифрази „добри витез“, она алтернира са личним именом. ${ }^{22}$ У роману се задржава двострука тачка виђења јунака, тако што се повезује или наизменично приказује поглед ликова који сведоче о Ланселотовој репутацији и свезнајући поглед. ${ }^{23}$ Ова перифраза се везује за мотив сазнавања имена, порекла и идентитета. Од тридесет две појаве, деветнаест се односе на лик Ланселота (59,375\%), три на Хектора (9,375\%), две на Бохорта (6,25\%), једна на Персевала (3,125\%) и седам на Галахада (21,875\%). Дистрибуција је таква да се учестало користе за Ланселота од првих подвига код Болне Страже до Галехотове смрти, да би се само једном користила током потраге Говена и четрдесеторице за Ланселотом, и то када један витез оспорава статус лика. Од Ланселотове потраге за Хектором до доласка Галахада на Артуров двор, ова перифраза се односи само на будуће трагаче за Гралом, чиме се најављује њихов значај у следећем роману циклуса. Што се тиче типа дискурса, директни говор ликова има предност над гласом свезнајућег приповедача, не толико по заступљености (58,974\% су директни говори ликова, 41,026\% интервенције приповедача), већ због тога што се у половини случајева интервенција приповедача преносе размишљања лика или речи у индиректном говору (20,51\%).

Хектора на самом почетку „добрим витезом“ називају његова драга, Синадос кога је ослободио и констабл који преноси вести Ивену и Сагремору, у истој епизоди где је назван „најбољим витезом на свету“. Бохорт се појављује као Ланселотов двојник у епизоди наставка „Колица“, где Госпа с Језера замера краљу Артуру што су допустили да оде „добри витез“; срамно обележје је укинуто кад Говен врати Бохорта на двор и када се краљ и краљица попну на колица.

21 „Именовање показује изабраног или одбаченог носиоца имена путем чуда које он или она спозна или у томе не успе током пустоловина."

22 Наводимо места на којима се јавља наведена перифраза: Micha, 1980a: 332, 336, 430, 431, 433, 441, 442; Micha, 1982: 30, 39, 73, 83, 84, 86, 95, 97, 155, 271, 304, 317; Micha, 1978a: 2, 55, 196, 345; Micha, 1978b: 35-36, 53, 57, 92; Micha, 1979: 127, 210; Micha, 1980b: 69, 117, 127 211; Micha, 1980c: 26, 191.

23 Сличан поступак постоји у стиховном роману Ивен или Вuтез са Лавом, види Obry, 2018: 52. 
На тај начин је прозни роман удвостручио брисање Ланселотове срамоте, преневши део заслуга на Бохорта. Персевал је налик „добром витезу“ по девичанству и заслужује место поред Опасног Седишта, на основу пророчанства неме девојке са Артуровог двора; ова врлина младог витеза ће се много пута хвалити у Потрази за Светим Гралом.

Лионел грешком од Говена који се бори код замка Леверзерп мисли да је „добри витез“ Галехот; то је један од неколико примера замене идентитета у роману. Пред крај романа ће Артурови витези мислити од Ланселота де је у питању сенешал Кеј, „најништавнији Артуров витез“, због опреме коју је грешком понео. Забуне у перцепцији у овим случајевима откривају истинити карактер ликова. Свега неколико поглавља раније Говена називају „најбољим витезом који је икада носио копље“, а његово име се потом записује на камену код Норгалског моста и у замку, чиме се слави његово витештво. У замку је записано име и другог „доброг витеза“, Хектора. Ланселот себе сматра лошим витезом у тренуцима безнађа.

Током првих подвига перифраза „добри витез“ којом се именује Ланселот самом неодређеношћу доприноси мистерији невидљивости непознатог витеза, кога одређују само дела која је учинио и због којих о њему круже вести и покреће се потрага. У рату Артура са Галехотом Ланселот дели овај надимак са својим полубратом, јунаком ослободиоцем Хектором. Захваљујући његовом изузетном витештву оба краља желе да буде уз њих, тако да настаје велика жалост када Галехот одведе „доброг витеза“ у своје краљевство Сорлоа. Због праведног освајања Болне куле, „доброг витеза“ моле за милост, а славе га на улицама зато што је излечио витеза у ковчегу, Дријана. У епизоди „Колица“ Ланселотов статус „доброг витеза који је дошао/долази да спаси краљицу“ и „ослободиоца заробљеника Краљевства без Повратка“ брише срамоту и друштвену осуду коју је претрпео „витез на колицима“. Истовремено се јављају два двојника, „добри витез који ће ускоро доћи“, „ослободилац Пустоловног Краљевства“, због којег Ланселот није више „најбољи витез на свету“, у епизоди на Светом Гробљу, а у „наставцима Колица“ Бохорт, други „добри витез“ на колицима срама, који ће допринети укидању овог лошег обичаја. Током боравка у затвору трију чаробница помоћ „доброг витеза“ недостаје сиротим девојкама, а његово одсуство ће сви осетити, како каже једна анонимна девојка. Она овом изјавом показује недостатак сажаљења витеза Округлог Стола над невољама слабих, пошто на Артуровом двору није добила помоћ за своју сестру. Убрзо после бега из затвора, Ланселот постаје заробљеник магичног кола, чију чаролију укида и потврђује да је онакав каквим га види краљица: „господин Ланселот“, „најлепши од свих и најбољи међу добрима“ (Micha, 1979: 353-354). Тек пред крај романа Ланселот престаје у потпуности да буде „добри витез“, а перифраза се односи на Галахада и Персевала. Перфиразом « li bons chevaliers qui de bonté et de chevalerie passera touz les chevaliers terriens » најављује се појава новог типа небеског витештва, заснованог на моралним врлинама, док Ланселот и Мордред посматрају поворку са белим јеленом; убрзо после тога, један пустињак релати- 
визује вредност ових земаљских витеза, називајући их « dui des plus maleureus chevaliers » (Micha, 1980b: 211, 220). ${ }^{24}$

При сусрету са другим ликовима, када један слуга жали због тога што је „најбољи витез на свету полудео“, када рањени домаћин не дозволи Ланселоту да покуша да га излечи као „најбољи витез на свету“, када се пустињак сажали на „доброг витеза који је изгубио разум“ или када сам Ланселот говори о себи као о „ономе који је некада био најбољи“, протагониста задржава надимак, али се он деградира, приближавајући се одређењима као што су „несрећни витез“, „болни витез“ или „замишљени витез“. Доналд Медокс (Donald Maddox) описује овакве ситуације као „сусрет у огледалу“ ("rencontre spéculaire »), који почива на довођењу у питање идентитета лика (Obry, 2018: 60).

\section{2. Остале перифразе}

Једна од улога перифраза је да истакну главно обележје јунаковог идентитета у одређеном тренутку радње романа. Оне се често јављају у уводним и завршним формулама, којима приповедач прекида ток приче и прелази на причу о неком другом лику, стварајући тзв. прерплетено приповедање.

Неке перифразе имају симболичко значење везано за идентитет или односе са другим ликовима. Тако је „витез са белом опремом“ јасно везан за вилински свет из којег је изашао како би се интегрисао у људски. Поред тога, у XIII веку било је уобичајено да нови витези током прве године носе бели штит без додатних обележја, што се помиње и у роману (Micha, 1982: 194). Ова перифраза алтернира са перифразама „витез који је освојио Болну Стражу“ и „нови витез“ током првих подвига и нестаје када се заврши прва потрага за Ланселотом и када Говен открије његово име на двору. Црвена боја витешке опреме, али и она која се јавља у опису Ланселотовог гнева, по Шарлу Мели симболизује митску црту келтског порекла јунака Ланселота, као и вилинску љубав и чини га предметом жеље за виле (1984: 349-351). „Црни витез“ по Мели представља предсказање Галехотове трагичне судбине (1984: 351). Доналд Медокс сматра да је један од разлога што Ланселот крије свој идентитет и то што се он сматра искључиво краљичиним витезом, па му је пре свега важно да га она препозна по штитовима разних боја (Maddox, 2007: 90). Слажемо се са Медоксовим запажањем да прогресија од беле опреме, преко црвене до црне не илуструје никакво негативно развијање на моралном плану, од невиности, крволочног насиља до пада, већ је то начин да се аутор поигра са хоризонтом очекивања, скривајући савршеног јунака под привидом било ког или чак злокобног витеза, чиме ствара « effets d'étrange » (2007: 95). ${ }^{25}$

Ланселот је и „ослободилац Болне Страже“: то је његов први велики подвиг којим ће задивити краљицу Гиневру. Госпа с Језера назива га „оним који је извором све њене радости“ (Micha, 1982: 462), а исту перифразу користи припове-

24 „добри витез који ће по доброти и витештву надмашити све земаљске витезе“; „двојицом најнесрећнијих витеза“

25 „ефекте чудног“ 
дач за краљицу у опису младог Ланселота. Истинитост овог одређења потврђују бројне сцене Гиневрине патње током Ланселотовог дугог одсуства са двора, у којима приповедач истиче да сви на двору такође тугују.

Ланселота карактерише и изузетна лепота, о чему сведоче називи које му додељују женски ликови: он је « li plus desirez chevaliers qui soit en terre » (Micha, 1978: 311), " li biaux, li bons, li mieldres de touz chevaliers, cil emprès qui toute prouesce doit faillir » (Micha, 1979: 111), « li plus biaux de touz et li mieldres des bons » (Micha, 1979: 354). ${ }^{26}$ Последње две перифразе показују да Гиневра и Артур веома слично опажају и вреднују Ланселота. „Најлепши витез на свету“ који је истовремено и веома племенит (« prudhomme »), поред епонимског јунака је и Говен, у једној епизоди на почетку романа (Micha, 1980a: 191). Ту слику Говена потврђује и његов портрет, где је приказан као витез који је имао бројне љубавне везе и који је увек био спреман да помогне свакоме ко од њега затражи помоћ.

Ланселота, међутим, током потрага за њим ликови и приповедач често доживљавају и именују као „болног витеза“, „сина болне краљице и краља умрлог од бола“ када је раздвојен од краљице или утамничен. На тај начин се припремају витезове тужбалице у којима евоцира све животне недаће и окрутну богињу Фортуну.

\section{5. Варијације личног имена}

Ванеса Обри, коментаришући повезивање крштеног имена са допуном која указује на порекло, друштвену припадност или географско порекло, наводи следеће запажање: «L'usage littéraire est loin de refléter exactement les mutations en cours de l'anthroponymie médiévale, mais les textes ne manquent pas d'exploiter cette relative instabilité du nom propre » (2017: 2) ${ }^{27}$. Ауторка сматра да фиктивна прича приказује предоминацију крштеног имена, које једино служи као стабилно обележје индивидуалног идентитета (Obry, 2017: 2-3). У Ланселоту у прози је управо питање идентитета проблематизовано, што се види већ на почетку романа, као што смо навели, где се јавља мотив изгубљеног крштеног имена. Природа свих пустоловина са којима се епонимски јунак сусреће везана је симболично за његова два имена.

Перифразе, проширене именске синтагме и поређења могу да сведоче о некој истакнутој особини лика, која се помиње у портрету код важнијих ликова или у проширеним личним именима код споредних ликова, а која се потврђује у њиховим делима.

Посебан углед и вредност витеза у друштву истичу се ако се уз његово име користи именица „господин“ уз посесив (mon seignor). Овај став истиче и Ванеса Обри, која напомиње: « La formule «mon seignor » (« mes sire » au cas

26 „Најпожељнији витез који постоји на земљи“; „лепи, добри, најбољи од свих витеза, онај после кога ће сва храброст нестати“; „најлепши од свих и најбољи међу добрима“

27 Књижевна употреба далеко је од тога да тачно одражава токове промена средњовековне антропонимије, али текстови не пропуштају да користе ту релативну нестабилност личног имена.“ 
sujet) [...] semble témoigner d'un figement comme titre de respect déjà acquis, le mot seigneur y ayant perdu son sémantisme féodal et le possessif ne renvoyant à aucune véritable première personne » (Obry, 2017: 3-4). ${ }^{28}$ Традиционално, она је најчешћа код лика Говена, који је на основу листе из романа Ерек и Енида Кретјена де Троа најбољи витез, док се Ланселот налази на трећем месту (Fritz et al., 1994: 113). Док је у Кретјеновим романима стих осмерац са парном римом могући разлог системске употребе титуле „mes sire/mon seignor“ уз двосложна имена Ивена и Говена, како наводи Обри (2017: 9), то није случај у прозном роману који анализирамо. Ми смо мишљења да је овакво именовање начин да аутор остане веран традицији, али и да истакне племенитост сваког лика уз чије име се помиње ова титула, а то су Ланселот, Галехот и краљ Артур. У прилог томе сведочи и именовање Ланселота као „господина Ланселота с Језера“ у тренутку када је он физички непрепознатљив због тровања: витез који га представља Хекторовом ујаку тиме му указује поштовање. Лепота и јунаштво протагонисте су сталне карактеристике у говорима ликова које среће, без обзира на то да ли је он болестан, заробљен или му је лепота нарушена, бројне перифразе сведоче о томе.

Када витез губи углед, ако се нађе у непријатељској земљи или ако учини нешто што је противзаконито, други ликови га ословљавају општим називом „младићу“ (vallet) који добија погрдну конотацију. Код неких ликова се уз углед губи и лично име, нпр. код Говена после Гралове поворке у Корбенику, којег један патуљак назива „лошим витезом“ (« malvais chevaliers »), да би га касније извели из замка на колицима срама; приповедачева перспектива је другачија, он га и даље назива „господином Говеном“ (Micha, 1978b: 371-386). Слична је ситуација у роману Витез са Лавом и уопште, код ликова Ивена и Говена, чије је окружено име знак достојанства, када се понашају у складу са принципима дворског друштва; када у епизоди лудила Ивен изгуби везу са цивилизацијом, име се ослобађа једног дела свог окружења (Obry, 2017: 12). Код Ланселота у прозном роману приметно је да га приповедач ословљава само личним именом у деловима текста у којима је тужан, меланхоличан или док изговара тужбалице. Могуће је тумачити и то скраћено име или као неки вид деградације лика, с обзиром да се то обично дешава када га воде у неки затвор, или пак као указивање на однос лика према сопственој судбини и драгим особама: нема Ланселота који не пати због раздвојености од краљице и од својих сабораца. У епизоди лудила на крају романа он губи у потпуности своје лично име, грађани Корбеника називају га «lе fol » („лудом“) или перифразама - мудри пустињак у шуми надомак Корбеника - «le plus biaux chevalier dou monde [...] fors del sens » („најлепшим витезом на свету [...] који је изгубио разум“), а краљ Пелес каже: « cil qui ert malades entr'ex avoit esté le millor chevalier dou monde » („онај који је болестан међу њима раније је био најбољи витез на свету“) (Micha, 1980с: 219, 218, 224).

28 „Формула „мој господине“ („мој господин“ у номинативу) [...] чини се да сведочи о устаљивању као титула о већ стеченом поштовању, пошто је реч господар ту изгубила феудално значење, а посесив не указује ни на какво стварно прво лице.“ 
У синтагми „Ланселот са Језера“ лично име се јавља уз предлошку синтагму која указује на географско порекло. Док Ванеса Обри истиче да се овакав израз у артуровским романима у стиху обично јавља приликом првог помињања лика, то није случај у прозном Ланселоту (Obry, 2017: 4). Кад је у питању Ланселотов углед, најсрамотнији назив ће бити перифраза „витез на Колицима“, док су увреде других витеза уобичајене у апострофима „зликовче“, „младићу“, „лоши витеже“ и сл. У прозном Ланселоту помиње се и „господин Ивен“ који помаже Ланселоту, нудећи се да буде заробљеник Дагенеа Луде уместо њега, као и „господин витез“, када краљ Артур при крају романа указује поштовање Ланселоту, најбољем витезу који је поразио све саборце Округлог Стола на турниру на Мадлену.

Именица „врли човек“ (prudhomme) сведочи о старијем поштеном и мудром аристократи висока рода који је морални узор другима. Овај надимак повезује Ланселотов лик са ликовима краљева Артура и Галехота. Занимљиво је да се у прозном Ланселоту, за разлику од већине средњовековних романа, лик детета или малолетне особе, које на старофранцуском изначава именица « enfes », за Ланселота се користи у лаудативним говорима, а не са пежоративном конотацијом особе која није зрела, којој недостају разум и мера. ${ }^{29}$ То је још једна одлика јединствености епонимског лика и поступак стварања онога што Медокс назива „ефектом чудног“.

Конструкција код које се лично име везује за именску групу коју чине детерминант и именица веома су честе у романима, ма какав био редослед двају конституената. Именска синтагма која следи после личног имена доноси додатну информацију о статусу или идентитету наведеног лика и омогућава да се идентификује референт; када детерминант и именица претходе личном имену, они представљају друштвену групу којој лик припада или подсећају на сродство (Obry, 2017a: 4). Такви су изрази „краљ Артур“, „краљица Гиневра“, „краљ Бан из Беноака“, „његов брат Лионел“, „његов брат Хектор“ итд. Кад је у питању Ланселотов лик, нема оваквих конструкција, премда бисмо могли да очекујемо изразе као што су „Ланселот наследник краљевства“ или „краљичин љубавник Ланселот“.

У изразима попут „Изолда плава“ (Ysolt la blonde), други члан је формуларна експанзија која се по навици везује за лично име; указујући на стабилну одлику лика, он функционише као природни епитет који има тенденцију да се интегрише уз име (Obry, 2017: 7). Код витеза који се сукобљавају са Ланселотом, при чему он показује своје врлине, јављају се неумереност („Сагремор Неумерени“ - "Sagremor Démesuré » или „Додинел Дивљи“ - « Dodinel le Sauvage ») или неприлагођеност и умна заосталост („Дагене Луди“ - "Daguenet le Fol“). У случају Ланселота нема сталне одлике лика, приповедач и ликови обично алтернирају лично име или га називају Ланселотом са Језера, када нису у питању перифразе. Некада су то међусобно заменљиве конструкције, али слажемо се са хипотезом ауторке Обри да „варијације окружења личног имена у изразима код

29 О сложеном приказу деце и прозном Ланселоту као роману о васпитању писала је Мишлин де Комбарје, види Combarieu, 1984: 101-136. 
којих су референти централни ликови доприносе начину на који јуначка фигура постаје упадљива“: « les variations de l'entourage du nom propre contribuent à révéler le mode de singularisation de la figure hérö̈que » (2017: 8). Један од најупечатљивијих случаја је израз „Несрећни Ланселот са Језера“ који на крају романа постаје „Несрећни Витез“, како епонимски јунак сам себе именује, што би могло да сведочи о томе да Ланселот од изузетне и јединствене индивидуе која има име од два члана постаје представник читаве класе несрећних витеза, а његово обележје, „несрећни“, топичка је одлика ове групе ликова.

С друге стране, Ланселот је описан као „чудесан“ и тајанствен, постаје предмет потрага Артурових витеза и предмет пожуде вилинских ликова, толико да једна девојка каже за њега, путем метонимије: "Or est venue la merveille » („Сада је чудо стигло“) (Micha 1978b: 100), док га три чаробнице по лепоти пореде са „вилењаком“ - «chose faée » (Micha 1979b: 173).

Изрази попут „тај Ланселот“ (li/cil Lacelotz), где се детерминант комбинује са личним именом, веома су ретки и код њих детерминант не мења референцијално и семантичко функционисање личног имена. Демонстративи се много чешће јављају уз бројне перифразе. Исти закључак има Обри код проучавања романа у стиху (2017: 7).

Кад је реч о томе у којој мери окружење имена доприноси везивању појединца за неку групу, сложили бисмо се са закључком Ванесе Обри да се окружење личног имена више односи на ликове који су у другом плану, у уводима или дигресивним одломцима, нпр. при набрајању витеза, док је за оне који су у првом плану за означавање довољно само лично име или, додали бисмо, нека карактеристична перифраза (2017: 10-11).

Ланселотово име потенцијално је метафорично: он је примерни представник куртоазне љубави. Шарлот Шапира (Charlotte Schapira) истиче да код употребе нелексикализованих или делимично лексикализованих личних имена књижевних или митских ликова ова имена увек означавају метафоре, или чак и хиперболе, пошто особа која се описује никада не досеже митску димензију коју докса везује за ова имена (2010: 5).

\section{6. Метафора цвета: витештво и љубав}

Метафора цвета везује лик Ланселота за краљицу Гиневру, Галахада и Хектора, док је у стиховним романима Кретјен де Троа овако именовао Говена. Јавља се у варијацијама у перифразама, којима се Ланселот именује седам пута (70\%), његов син Галахад два пута (20\%), а полубрат Хектор једном (10\%). Галехот први употребљава израз „цвет свих витезова на свету“, приликом уговарања његовог састанка са Гиневром (Micha, 1982, 102). ${ }^{30}$ Госпа с Језера назива га „господаром и цветом читавог света“ (Micha, 1982, 461). ${ }^{31}$ Приликом најезде Саксона краљица жали што „цвет витештва“ није ту (Micha, 1982: 455); ослобођени витези

30 « la flors des chevaliers de tout le monde "

31 « le seignor et la flor de tot cest monde» 
Терикановог брежуљка користе исти израз.32 Племенитост и поштовање обичаја хвали један витез из Гора, коме је Ланселот дао другу прилику да се одбрани, пошто је затражио милост (Micha, 1978b: 56). Кеј га назива „цветом земаљског витештва“ после победе над Мелеаганом (Micha, 1979b: 107). ${ }^{33}$ На двору сви тугују, верујући да је „цвет овога света“, „цвет земаљског витештва“ мртав (Micha, 1978b: 307, 309). ${ }^{34}$ Хектора славе као ослободиоца замка Маригара Црвеног и Ланселотове рођаке Ангале (Micha, 1978b: 397). Бохорт се радује када чује предсказање да ће Ланселотов син постати „цвет витештва“ (Micha, 1980с: 59).

По правилима куртоазне љубави најбољи витез заслужује љубав најлепше жене највишег друштвеног положаја. Ликови су савршено складни и достојни једно другог, што је симболично приказано и путем чудесног штита чије се две половине стапају када љубав заживи. Краљицу „цветом међу госпама“ назива племенити Галехот, који ће и клерика Елија из Тулуза назвати „цветом међу клерицима“. Тако се оправдава грешна прељуба витеза и краљице, која је благотворна за друштво. Друга грешна веза, са Амитом, изнедриће честитог Галахада, преко потребног артуровском свету испуњеним насиљем. „Цвет девичанства“ лепе ћерке Краља Рибара се жртвује за опште добро, а грехе оца откупљује онај који је „цвет и огледало витештва“ (Micha, 1979: 211). ${ }^{35}$ Прво је Ланселот довео у питање вредност најбољег витеза Говена, да би потом Галахад најавио сасвим нову концепцију небеског витештва и преиспитивање сврхе земаљских подвига и пустоловина, о чему сведочи израз „огледало витештва“.

\section{7. Закључак}

Ланселот или „Бели Витез“, „Црвени Витез“, „Црни Витез“, „најбољи витез на свету“, „Добри Витез“, „цвет свих витезова“, „онај који ће осветлити сво земаљско витештво“, „цвет земаљског витештва“, „витез који је све победио“, „витез који је убио џинове“, „најбољи витез на свету у овом тренутку/међу онима који сада живе“, „најчудеснији човек, цвет витештва, и најчаснији човек на свету“ „несрећни витез који је због свог несрећног телесног греха пропустио да заврши чудесне пустоловине Грала, на које никада неће моћи да положи право“, „несрећни витез који је некада био најбољи, несрећни Ланселот с Језера“, „некада најбољи витез на свету“ и најзад, „Несрећни Витез“, једна је од кључних митских фигура које је изнедрио француски Средњи век. Тајанствен и неухватљив попут Светог Грала, овај лик пролази кроз сталне трансформације. Он је „почетак и крај потраге“, како га назива приповедач, потраге за смислом витештва и испуњењем своје судбинске мисије: бранитељ краљевства, јунак ослободилац, узорни витез, краљичин љубавник постаје један од узрока распада Артуровог краљевства. Изгубивши крштено име „Галахад“, Ланселот сам мора да изгради своје име и славу, ослањајући се на слободну вољу.

32 « la flors des chevaliers del monde »

33 " la flors de la terrienne chevalerie "

34 «la flors del monde "

35 « la flor et mireor de chevalerie » 
Идентитет протагонисте Ланселота у прози стално се мења, о чему сведоче и начини на који га именују приповедач и други ликови, као и он сам. Извесне перифразе и надимке Ланселот дели са другим ликовима, пре свега Галахадом, захваљујући чему се припрема Потрага за Светим Гралом. Перифразе које га славе често се налазе близу оних које указују на његове слабости и недостатке, сведочећи о променљивости људске судбине. Само лично име, без ознаке о пореклу, знак је јунакове деградације и неактивности на плану романескне радње. Слика Ланселота је релативизована и његова слава је на заласку у одосу на хвале које већ у овом роману добија његов син Галахад. Промене његовог идентитета сведоче о стању Артуровог света земаљских витеза, а у једном ширем контексту о слави овога света која је пролазна, која нестаје, али вреди да остане у сећању будућих генерација, у „причи о Ланселоту с Језера“, која сведочи о сталној људској тежњи за самопревазилажењем и усавршавањем.

\section{Литература}

Клајн, И., Шипка, М. (2007). Велики речник страних речи и израза. Нови Сад: Прометеј.

[Klajn, I., Šipka, M. (2007). Veliki rečnik stranih reči i izraza. Novi Sad: Prometej]

Combarieu, M. de. (1984). Le Lancelot comme roman d’apprentissage. Enfance, démesure et chevalerie. In J. Doufournet (Éd.), Approches du Lancelot en prose (pp. 101-136). Paris : Champion.

Combes, A. (2000). Les Voies de l'aventure. La réécriture et la composition dans le Lancelot en prose. Paris : Honoré Champion.

Faral, E. (1982). Les arts poétiques du XII et du XIII siècle. Recherches et documents sur la technique littéraire du moyen âge. Genève : Slatkine.

Kelly, D. (1992). The Art of Medieval French Romance. Madison: University of Wisconsin Press.

Maddox, D. (2007). Sens et conjointure dans le Lancelot propre. Cahiers de recherches médiévales, 14, 87-100. DOI: 10.4000/crm.2657

Méla, Ch. (1984). La reine et le Graal. La conjointure dans les romans du Graal, de Chrétien de Troyes au Livre de Lancelot. Paris : Seuil.

Obry, V. (2017). L'entourage du nom propre dans le roman médiéval : Chrétien de Troyes et Jean Renart. In N. Laurent et C. Reggiani (Éds.), Seuils du nom propre (pp. 23-34). Limoges : Lambert-Lucas. Academia. https://www.academia.edu/35488251/_L_ entourage_du_nom_propre_dans_le_roman_m\%C3\%A9di\%C3\%A9val_ Chr\%C3\%A9tien_de_Troyes_et_Jean_Renart_dans_Seuils_du_nom_ propre_dir_Nicolas_Laurent_et_Christelle_Reggiani_Limoges_Lambert_ Lucas_\%C3\%89tudes_linguistiques_et_textuelles_2017_p_23_34?email_work_ card=view-paper [10.06.2021]

Obry, V. (2018). 'Celui qui le jaiant ocist'. Réflexions sur le nom et ses substituts dans le Chevalier au lion. In A. Mussou, A. Paupert et M. Szkilnik (Éds.), "Chose qui face a escouter » : études sur le Chevalier au lion de Chrétien de Troyes (pp. 51-62). Paris : Université Paris-Diderot Paris 7/Université Sorbonne Nouvelle Paris 3. 
Poirion, D. (1988). Le roman d'aventure au Moyen Age : étude d'esthétique littéraire. Cahiers de l'Association internationale des études françaises, 40, 111-127.

Schapira, Ch. (2010). Une définition doxale : les noms propres potentiellement métaphoriques. Publifarum, 11, 1-11.

Séguy, M. (1996). D’armes et d’amour, à corps perdu. In M. Séguy (Éd.), Lancelot (pp. 7-32). Paris : Autrement.

\section{Извори}

Fritz, J.-M. et al. (Éd.). (1994). Troyes, Chrétien de, Romans, suivis des Chansons, avec, en appendice, Philomena. Paris : Livre de Poche.

Micha, A. (Éd.). (1978a). Lancelot. Roman en prose du XIII siècle. Tome I. Paris : Droz. Micha, A. (Éd.). (1978b). Lancelot. Roman en prose du XIII siècle. Tome II. Paris : Droz. Micha, A. (Éd.). (1979). Lancelot. Roman en prose du XIII siècle. Tome IV. Paris : Droz. Micha, A. (Éd.). (1980a). Lancelot. Roman en prose du XIII siècle. Tome VII. Paris : Droz. Micha, A. (Éd.). (1980b). Lancelot. Roman en prose du XIII siècle. Tome V. Paris : Droz. Micha, A. (Éd.). (1980c). Lancelot. Roman en prose du XIII siècle. Tome VI. Paris : Droz. Micha, A. (Éd.). (1982). Lancelot. Roman en prose du XIII siècle. Tome VIII. Paris : Droz. Micha, A. (Éd.). (1983). Lancelot. Roman en prose du XIII e siècle. Tome IX Index des Noms propres et des Anonymes. Index des Thèmes, des Motifs et des Situations. Glossaire. Notes complémentaires. Errata. Paris : Droz.

\section{Zorana V. Krsmanović}

\section{Summary}

\section{REFLECTIONS ON THE EXPANDED PROPER NOUNS AND PERIPHRASIS IN THE PROSE LANCELOT}

This paper aims to analyze the use of expanded proper nouns and periphrasis referring to the eponymous character in the Old French romance the prose Lancelot, written between 1215 and 1230, the central part of the Vulgate or Lancelot-Graal cycle. The periphrasis and (expanded) proper nouns reveal the relationships between characters, as well as the relationship between the character and the Arthurian society. They also attest to the evolution of the identity of the protagonist and are therefore important for the composition and the link between the prose Lancelot and other romances, such as the Quête du Saint Graal, which it paves the way for in a sense, and the Chevalier de la Charrette of Chrétien de Troyes, which inspired the anonymous author of the romance that we are analyzing. The use of proper nouns and periphrasis reveals different conceptions of the Romanesque character.

\section{Key words:}

the prose Lancelot, French literature, $13^{\text {th }}$ century, romance, character, periphrasis, expanded proper noun 


\section{Zorana V. Krsmanović}

Résumé

\section{RÉFLEXIONS SUR LE NOM PROPRE ET LES PÉRIPHRASES DANS LE LANCELOT EN PROSE}

Ce travail porte sur le roman français médiéval, le Lancelot en prose, écrit entre 1215 et 1230, la partie centrale du cycle romanesque Lancelot-Graal ou le cycle de la Vulgate, précédé par l'Histoire du Saint Graal et le Merlin et suivi par la Quête du Saint Graal et la Mort du roi Arthur. Nous analysons le fonctionnement et les implications stylistiques des périphrases et des entourages du nom propre du héros éponyme Lancelot. Les périphrases et les noms propres dans des contextes narratifs différents démontrent les relations entre certains chevaliers auxquels ils se réfèrent et la société courtoise arthurienne, témoignent de l'évolution du personnage, de son identité, des liens entre certains personnages. Ces expressions ont un rôle important dans la composition du récit, ainsi que dans le reliment du Lancelot en prose avec d'autres romans du cycle de la Vulgate, notamment avec la Quête du Saint Graal, qu'elles préparent. Les emplois du nom propre et des périphrases rendent ainsi compte des conceptions différentes du personnage romanesque et de la construction du héros éponyme.

\section{Mots-clés:}

Lancelot en prose, littérature française, XIIIe siècle, roman, personnage, périphrase, entourage du nom propre 